\title{
Feeding and lying behavior of heat-stressed early lactation cows fed low fiber diets containing roughage and nonforage fiber sources
}

\author{
J. Kanjanapruthipong, ${ }^{1}$ W. Junlapho, and K. Karnjanasirm \\ Department of Animal Science at Kampaengsaen, Kasetsart University, Kampaengsaen, Nakornpathom, 73140, Thailand
}

\begin{abstract}
In addition to reduced nutrient intake, an environmental thermal load may directly affect milk yield in heat-stressed dairy cows. Feeding and lying behaviors of early lactation cows fed low fiber diets containing neutral detergent fiber (NDF) from roughage and nonforage fiber sources (NFFS) were investigated under summer conditions in Thailand. Immediately after calving, 30 multiparous cows $(87.5 \%$ Holstein $\times 12.5 \%$ Sahiwal $)$ were randomly allocated to dietary treatments for $63 \mathrm{~d}$ in a completely randomized design. The dietary treatments contained $25 \%$ of dry matter (DM) as dietary NDF. The control diet consisted of $13.9 \%$ roughage NDF from rice straw (RS). Two additional treatments were created by replacing $3.9 \%$ of DM with NDF from either soy hulls (SH) or cassava (Manihot esculenta Grantz) residues (CR), so that the roughage NDF content was reduced to $10 \%$. During the experimental period, the minimum and maximum temperature-humidity indices (THI) were $86.4 \pm 2.5$ and $91.5 \pm 2.7$ during the day and $74.2 \pm 2.1$ and $81.0 \pm 2.5$ during the night, respectively, indicating conditions appropriate for induction of extreme heat stress. The duration of feeding and lying bouts decreased linearly with increasing THI. The DM intake during the day was greater for cows fed diets containing SH and CR than for those fed the diet containing NDF from RS. The number of meals during the day and night was lower, whereas meal size and meal length during the day and night were greater for cows fed diets containing SH and CR. Cows fed diets containing $\mathrm{SH}$ and $\mathrm{CR}$ lay down less frequently and longer during the day. These results suggest that under the severe heat stress during the day, early lactation cows fed the diet containing NFFS increased DM intake by increasing meal length and meal size rather than by increasing meal frequency and they spent more time lying. Cows fed diets containing NDF from SH and CR produced more $4 \%$ fat-corrected milk, lost less body weight, and had lower rectal temperatures measured at
\end{abstract}

Received March 21, 2014.

Accepted October 29, 2014.

${ }^{1}$ Corresponding author: agrjck@ku.ac.th the $1530 \mathrm{~h}$ milking. Therefore, reducing the filling effect may contribute to reducing heat load derived from the change in feeding and lying behavior. This should be considered as a factor for impairing productivity of heat-stressed early lactation cows.

Key words: early lactation cow, heat stress, feeding behavior, lying behavior

\section{INTRODUCTION}

Increased heat load elicits physiological and behavioral responses, including increased core body temperature, respiration, reduced feed intake, reduced physical activity, and decreased milk yield (Collier et al., 1982). Reduced nutrient intake is primarily responsible for the diminished milk synthesis (Collier et al., 1982); however, it accounts for only about $50 \%$ of the decrease in milk synthesis (Rhoads et al., 2009), and lactating cows exhibit behavioral changes in feeding and lying when exposed to increasing heat load (Legrand et al., 2011). In addition to its effect on nutrient intake, an environmental thermal load may directly affect milk yield in heat-stressed dairy cows.

Cows in early lactation spend more time eating and less time lying than cows in late lactation (Nielsen et al., 2000). Cows fed a high silage diet also spend more time eating and less time lying (Nielsen et al., 2000) and have a greater daily roughage intake by increasing meal size rather than by increasing meal frequency, regardless of whether concentrate is consumed (Morita et al., 1996). A reduction in the time that cows spend lying can have a negative effect on blood flow to the mammary gland (Rulquin and Caudal, 1992) and the gravid uterus (Nishida et al., 2004). In addition, less lying time is a risk factor for lameness in cows housed in freestall systems (Chapinal et al., 2009). However, time constraints on both lying and eating behavior at the same time may reduce milk production (Munksgaard et al., 2005). Cows suffering from heat stress eat more frequently, consume smaller meals, and spend less time lying than those not heat stressed (Shiao et al., 2011). Whether a change in feeding and lying behavior of heat-stressed cows is biologically significant to lactation performance is of interest. 
Under a high heat load, physical factors derived from a higher fiber diet have greater hypophagic effects (Kanjanapruthipong et al., 2010). A nutritional approach to minimize the negative effect of heat stress on DMI is the partial replacement of roughage NDF with more digestible NDF sources from by-product feeds known as nonforage fiber sources (NFFS; Halachmi et al., 2004). However, little is known about how the source and amount of fiber affect heat-stressed dairy cows. Information on variation in feeding and lying behavior and production is limited for severely heatstressed early lactation cows fed low fiber diets containing NDF from roughage and NFFS. The objectives of the current study were to determine the effects of low fiber diets containing roughage and NFFS on feeding and lying behavior, DMI, and lactation performance of heat-stressed early lactation cows.

\section{MATERIALS AND METHODS}

\section{Experimental Design and Management of Cows}

The Animal Care and Use Committee at Kasetsart University approved the experimental procedures used in this study. A study was conducted during summer months, from March 26 to May 27, 2012, and was undertaken at the WataKan dairy farm (a commercial dairy farm at Kampaengsaen, Nakornpathom Province, Thailand; $\left.13^{\circ} 55^{\prime} \mathrm{N}, 100^{\circ} 7^{\prime} \mathrm{E}\right)$.

Thirty crossbred cows $(87.5 \%$ Holstein $\times 12.5 \%$ Sahiwal) in their second and third lactations were dried off $60 \mathrm{~d}$ before their expected calving date and assigned immediately to a nonlactating diet with energy content close to $( \pm 0.05 \mathrm{Mcal} / \mathrm{kg}$ of $\mathrm{DM})$ the $\mathrm{NE}_{\mathrm{L}}$ requirement defined by NRC (2001). Body weight with conceptus, BW change, DMI, days pregnant, and calf birth weight were used as model inputs. Mild heat stress has been estimated to increase the maintenance energy requirement by $7 \%$ (NRC, 2001). Estimated diet energy concentrations (NRC, 2001) were calculated by summing the $\mathrm{NE}_{\mathrm{L}}$ (Mcal) from maintenance $[(0.08+0.08 \times$ $0.07)$ Mcal of $\mathrm{NE}_{\mathrm{L}} / \mathrm{kg}$ of $\left.\mathrm{BW} \times \mathrm{BW}^{0.75}\right]$, required for pregnancy $[(0.00318 \times$ days pregnant -0.0352$) \times($ calf birth weight $/ 45)] / 0.218$, and $\mathrm{BW}$ change (BW change $\times 5.34 \mathrm{Mcal}$ of $\mathrm{NE}_{\mathrm{L}} / \mathrm{kg}$ of $\mathrm{BW}$ ), and then dividing the sum by DMI. Cows were kept in an opened 3-sided barn in one large pen and fed as a group during the nonlactating period. A prepartum diet was fed only for the 3 wk before expected calving date. Cows consumed the prepartum diet for $18.9 \pm 0.9 \mathrm{~d}$. At parturition, BCS of the cows was $3.38 \pm 0.06$ (on a scale of 1 to 5 ). All animals calved once the experiment began and were moved to an opened 3-sided barn after calving and were housed individually in stalls throughout the experimen- tal period of $63 \mathrm{~d}$. The barn measured $12 \times 36 \times 3 \mathrm{~m}$ (width $\times$ length $\times$ height) with an east-west aspect. The barn contained 40 stalls configured in 2 rows of 20 stalls each; these 2 rows were separated by a feeding alley. Stalls measured $150 \times 300 \mathrm{~cm}$, were equipped with rubber floormats ( $2 \mathrm{~cm}$ thick), and had individual feed and water troughs. The prevailing winds during this time of the year are from the southwest toward the northeast at $2.7 \pm 0.4 \mathrm{~km} / \mathrm{h}$ (monthly reports from the meteorological station at Kampaengsaen, Nakornpathom Province). The 2 stalls on the eastern end and the 3 stalls at the western end of each row were not used. The experimental stalls were allocated to 10 groups of 3 adjacent stalls. The experimental cows were randomly assigned to individual dietary treatments. Each cow with a different dietary treatment was randomly assigned to 1 of a group of 3 stalls. Therefore, each cow with different dietary treatments was housed next to each other. The experimental cows were distributed equally throughout the barn. All stalls were cleaned before the 0430 and $1530 \mathrm{~h}$ milkings. Cows had no supplemental cooling from fans or misters.

Soy hulls (SH) were defined as a high NDF ingredient and cassava residues (CR) were defined as a low NDF ingredient. Both SH (Ipharraguerre and Clark, 2003) and CR (Kanjanapruthipong and Buatong, 2004) are characterized by low lignin concentrations, a rapid rate of fermentation, and high digestibility. Soy hulls and CR were used as NFFS. Rice straw (RS) was cut using a motorized chopper (Rice straw specific model, Department of Agricultural Engineering, Kasetsart University, Nakornpathom Province, Thailand) to a particle length of approximately $2.0( \pm 0.2) \mathrm{cm}$ and used as a source of roughage. The dietary treatments contained $25 \%$ of DM as dietary NDF. The control diet consisted of $13.9 \%$ roughage NDF from RS and $11.1 \%$ concentrate NDF. The roughage NDF content for 3.9\% of DM was replaced with NDF from either SH or CR, so that the roughage NDF content was decreased to $10 \%$ (Table 1). The dietary treatments were mixed daily and fed as a TMR. Approximately half of each day's TMR was fed in the morning $(0630 \mathrm{~h})$ and the other half in the afternoon $(1830 \mathrm{~h})$. Refused feed was weighed before the morning and afternoon feeding, and the amount of feed offered was adjusted daily to allow $10 \%$ refusal.

The ambient temperature and relative humidity (RH) were recorded continuously by a thermograph (8613, B. S. 3231, Classell, London, UK) placed in the middle of the barn approximately $1.5 \mathrm{~m}$ above the feeding alley floor. The maximum and minimum ambient temperature and $\mathrm{RH}$ were determined for each day. The temperature humidity index (THI) was calculated using the equation THI $=(1.8 \times \operatorname{td}+32)-(0.55-$ 
Table 1. Ingredient and chemical composition of the experimental diets

\begin{tabular}{|c|c|c|c|}
\hline \multirow[b]{2}{*}{ Item } & \multicolumn{3}{|c|}{ Treatment $^{1}$} \\
\hline & RS & $\mathrm{SH}$ & $\mathrm{CR}$ \\
\hline \multicolumn{4}{|l|}{ Ingredient, $\%$ of DM } \\
\hline Soybean meal & 7.3 & 7.3 & 7.3 \\
\hline Mungbean meal & 24.5 & 24.5 & 24.5 \\
\hline Wheat bran & 8.0 & 8.0 & 8.0 \\
\hline Sesame seed meal & 10.5 & 9.1 & 10.5 \\
\hline Soy sauce residues & 5.6 & 5.6 & 5.6 \\
\hline Cassava chips & 22.8 & 23.0 & 18.1 \\
\hline Minerals and vitamins ${ }^{2}$ & 2.5 & 2.5 & 2.5 \\
\hline Soy hulls & - & 6.5 & - \\
\hline Cassava residues & - & - & 10.0 \\
\hline Rice straw & 18.8 & 13.5 & 13.5 \\
\hline \multicolumn{4}{|l|}{ Chemical composition, $\%$} \\
\hline $\mathrm{CP}$ & 16.9 & 16.8 & 17.0 \\
\hline $\mathrm{NDF}$ & 25.1 & 25.0 & 25.2 \\
\hline Roughage NDF & 13.9 & 10.0 & 10.0 \\
\hline $\mathrm{NE}_{\mathrm{L}},{ }^{3} \mathrm{Mcal} / \mathrm{kg}$ of $\mathrm{DM}$ & 1.64 & 1.65 & 1.64 \\
\hline \multicolumn{4}{|c|}{${ }^{1} \mathrm{RS}=$ rice straw; $\mathrm{SH}=$ soy hulls; $\mathrm{CR}=$ cassava residues. } \\
\hline \multicolumn{4}{|c|}{$\begin{array}{l}{ }^{2} \mathrm{Contained} \text { (per } \mathrm{kg} \text { of DM) } 65 \mathrm{~g} \text { of Ca, } 10.1 \mathrm{~g} \text { of } \mathrm{K}, 4.2 \mathrm{~g} \text { of } \mathrm{P}, 2.8 \mathrm{~g} \text { of } \mathrm{Cl}, 2.3 \mathrm{~g} \text { of } \mathrm{Mg}, 2.3 \mathrm{~g} \text { of S, } 2.0 \mathrm{~g} \text { of Na, } \\
56 \mathrm{mg} \text { of } \mathrm{Fe}, 45.3 \mathrm{mg} \text { of } \mathrm{Mn}, 45.3 \mathrm{mg} \text { of } \mathrm{Zn}, 11.4 \mathrm{mg} \text { of } \mathrm{Cu}, 0.68 \mathrm{mg} \text { of I, } 0.34 \mathrm{mg} \text { of Se, } 0.11 \mathrm{mg} \text { of Co, } 3,600 \\
\mathrm{IU} \text { of vitamin A, } 1,128 \mathrm{IU} \text { of vitamin D, and } 28 \mathrm{IU} \text { of vitamin } \mathrm{E} \text {. } \\
\left.{ }^{3} \mathrm{NE}_{\mathrm{L}} \text { (Mcal } / \mathrm{kg}\right)=0.0245 \times \mathrm{TDN}(\%)-0.12 \text {; the TDN value was calculated from composition data and TDN } \\
(\%)=\text { tdNFC }+ \text { tdCP }+ \text { tdFat }+ \text { tdNDF }-7 \text {; where td is truly digestible; tdNFC, tdCP, tdFat, and tdNDF } \\
\text { were calculated using the equations of NRC }(2001) \text {. }\end{array}$} \\
\hline
\end{tabular}

$0.0055 \times \mathrm{RH}) \times[(1.8 \times \mathrm{td}+32)-58)]$, where $\mathrm{td}$ is the dry bulb temperature $\left({ }^{\circ} \mathrm{C}\right)$ and $\mathrm{RH}$ is the relative humidity (NOAA, 1976).

\section{Data Collection, Sampling Procedures, Calculations, and Statistical Analysis}

Samples $(2 \pm 0.1 \mathrm{~kg}, \mathrm{n}=3)$ of the TMR were obtained weekly and analyzed for DM and CP contents. The DM and CP of the experimental diets were determined according to methods described by AOAC (1980). Heat-stable $\alpha$-amylase (A3306; Sigma Chemical Co., St Louis, MO) was used to remove starch, and sodium sulfite was used to dissolve cross-linked proteins in the NDF procedure according to the method of Van Soest et al. (1991).

Feeding and lying behavior for each cow were recorded continuously using infrared video cameras (Fujiko CCTV, Specialist model H.264, New Taipei, Taiwan) fitted with 24.5-mm lens (CCTV lens, Adtech, Taiwan). Cameras were connected to a digital video recorder (RS-485 Multiplex Digital Watermark System, Fujiko, Taiwan). Each stall was equipped with 2 infrared cameras placed approximately $3 \mathrm{~m}$ from the stall floor and $2 \mathrm{~m}$ in front of the stalls so that the whole pen and the feeding area could be seen.

Previous research has shown substantial betweencow variation and several changes in feeding and lying behavior from early to peak lactation. An assessment of dietary treatment effects on these behaviors should control DIM, and a minimum of 3 consecutive days for the behavior measures is recommended in the literature (Metz, 1985; DeVries et al., 2003). The feeding and lying behavior for each cow was collected from continuous 72 -h video recording by multiple trained observers for 2 periods from d 27 to 29 and from d 57 to 59 after calving. Interobserver reliability, as measured by percentage of agreement, averaged $99 \pm 1 \%$ for time spent eating, the periods within a meal spent not eating, and the periods between meals, and $99.5 \pm 0.5 \%$ for time spent lying.

For each feeding bout, the time the bout began and ended were recorded. The periods within a meal spent not actually feeding and the periods between meals were also recorded. To group short feeding bouts into meals and the longest nonfeeding interval that was still accepted as an interval within a meal, meal criteria were then calculated by fitting the frequency distribution of intervals between and intervals within meals to a double log-normal model. The meal criterion was determined as the point at which the distribution curve of intermeal intervals intersected the distribution curve on intrameal intervals. Daily meal frequency for each cow was determined by counting the frequency of intervals between visits to the feed trough that exceeded the meal criterion. Daily meal time was calculated as the sum of all recorded feeding time and all nonfeeding periods shorter than the meal criterion. 
For each lying bout with flank in contact with the ground, the time the bout began and the time the bout ended were recorded. The lying duration $(\mathrm{h})$ was calculated as the time from the start of the lying bout to the end of lying bout in one lying.

The cows were milked twice daily at 0430 and 1530 $\mathrm{h}$ with a portable milking unit, and milk weights were recorded. It took around 40 min to milk 30 cows during each period. The BW of the cows were recorded on $\mathrm{d} 0$, $5,12,19,26,33,40,47,54$, and 61 of the study before the morning feeding, and BCS were assigned weekly by the same individual for the entire experiment, using a scale from 1 to 5 following the method of Wildman et al. (1982), with quarter-point increments. Rectal temperature was recorded every $7 \mathrm{~d}(\mathrm{~d} 4,11,18,25$, $32,39,46,53$, and 60 of the study) after the morning and afternoon milking by using a clinical thermometer (HF 365, Philips, Shanghai, China) inserted into the rectum.

Milk was sampled twice weekly from consecutive morning and afternoon milking sessions. The milk samples were composited in proportion to milk production at each sampling and were preserved with 2-bromo-2-nitropropane-1,3-diol for analysis of their composition. Milk components were assayed for fat, total protein and lactose using a MilkoScan (Bentley Somacount 2000, Bentley, Chaska, MN).

Net energy intake $\left(\mathbf{N E}_{\mathbf{I}}\right), \mathrm{NE}_{\mathrm{M}}$, and $\mathrm{NE}_{\mathrm{L}}$ were used as model inputs. Energy balance (EB) was calculated (NRC, 2001) individually for each cow. The $\mathrm{NE}_{\mathrm{I}}$ was determined by multiplying daily DMI by the calculated energy value of the experimental diets. Severe heat stress has been estimated to increase the maintenance energy requirement of dairy cows by $25 \%$ (NRC, 2001). The $\mathrm{NE}_{\mathrm{M}}$ was calculated as $\mathrm{BW}^{0.75} \times 0.08 \times 0.25$, where $\mathrm{BW}^{0.75}=$ metabolic $\mathrm{BW}$. The $\mathrm{NE}_{\mathrm{L}}$ requirement was calculated as $(0.0929 \times$ fat $\%+0.0547 \times \mathrm{CP} \%+$ $0.0395 \times$ lactose $\%) \times$ milk yield. Energy balance was calculated as follows: $\mathrm{EB}=\mathrm{NE}_{\mathrm{I}}-\left(\mathrm{NE}_{\mathrm{M}}+\mathrm{NE}_{\mathrm{L}}\right)$.

The data during the day were collected between 0600 and $1800 \mathrm{~h}$ and those during the night were recorded from 1800 to $0600 \mathrm{~h}$. The data for DMI and milk yield were reduced to weekly means for each cow before being statistical analyses. Milk yield, DMI, BW, and rectal temperature data were subjected to ANOVA for a completely randomized design with repeated measurement using the GLS function of R (version 2.9.0; R Foundation, 2009; http://www.r-project). The model included the fixed effects of diet and time and the interaction of diet and time. Cow nested within diet was designated as a random effect and was used as the error term to test the effects of diet. The covariance structure of repeated measurement that yielded the smallest Bayesian information criterion was chosen. The contrasts state- ment with the frame "longa coding for tf" was used to test for the effects of diet at a specific time point. Data during the day and night for feeding and lying behavior from multiple days per cow and treatment were reduced to daily means. The data of the individual behavior criterion were assessed separately using ANOVA for a completely randomized design. The difference between treatment means was analyzed by least significant difference. Least squares means and standard errors of the means were reported for all ANOVA results.

\section{RESULTS}

During the experimental period, the average (mean $\pm \mathrm{SD}$ ) minimum and maximum temperatures were 35.2 \pm 2.3 and $41.0 \pm 2.8^{\circ} \mathrm{C}$ during the day and $23.5 \pm 2.6$ and $29.1 \pm 3.1^{\circ} \mathrm{C}$ during the night, respectively. The average (mean $\pm \mathrm{SD}$ ) minimum and maximum $\mathrm{RH}$ were $45.3 \pm 3.4$ and $55.7 \pm 3.7 \%$ during the day and 93.4 \pm 2.6 and $97.9 \pm 2.9 \%$ during the night, respectively. The combination of high temperature and RH led to significant minimum and maximum THI (mean \pm SD), which averaged $86.4 \pm 2.5$ and $91.5 \pm 2.7$ during the day and $74.2 \pm 2.1$ and $81.0 \pm 2.5$ during the night, respectively.

The behavior of feeding and lying is given in Table 2. Meal length ( $\mathrm{min} / \mathrm{meal})$ and meal size during the day and night were greater $(P<0.01)$ in cows fed the $\mathrm{SH}$ and CR diets compared with cows fed RS diet. Frequency of meals during the day $(P=0.03)$ and during the night $(P=0.02)$ was affected by dietary treatment. Cows fed diets containing NDF from SH and CR had fewer meals. Meal length ( $\mathrm{min} / \mathrm{meal}$ ) and meal size during 27 to 29 DIM and 57 to 59 DIM during the day and night were greater $(P<0.01)$ in cows fed diets containing NDF from SH and CR. The changes in feeding bout duration ( $\mathrm{min}$ ) related to THI are shown in Figure 1 , and the $P$-values for linear and quadratic effects were $<0.01$ and $<0.01$, respectively. Dietary treatments had no effect on meal time $(\mathrm{min} / \mathrm{d})$. Frequency of lying during the day was lower $(P<0.01)$ and duration of lying during the day was longer $(P<0.01)$ for cows fed diets containing NDF from SH and CR. Dietary treatments had no effect on lying behavior during the night. Changes in lying bout duration (min) related to THI are illustrated in Figure 2, and the $P$-values for linear and quadratic effects were $<0.01$ and 0.15 , respectively.

The effects of dietary treatment on DMI, changes of $\mathrm{BW}$ and $\mathrm{BCS}$, and rectal temperature are presented in Table 3. The DMI during the day was greater $(P$ $<0.01)$ for cows fed diets containing NDF from $\mathrm{SH}$ and CR. The BCS $(P=0.03)$ and changes in BCS $(P$ $=0.04)$ and $\mathrm{BW}(P=0.02)$ were affected by dietary treatment. Cows fed the diets containing NDF from $\mathrm{SH}$ 


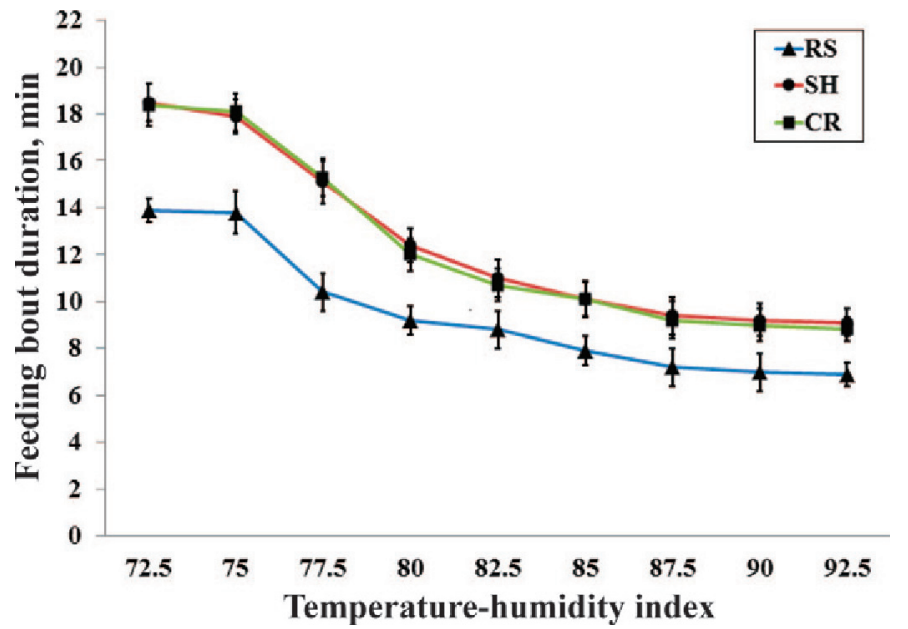

Figure 1. Changes in feeding bout duration (min) related to temperature-humidity index (THI) in cows fed diets containing rice straw (RS), soy hulls $(\mathrm{SH})$, or cassava residues (CR). The data for feeding bout duration during the night were at and below THI of 82.5 and those during the day were above THI of 82.5 . Feeding bout duration SEM was $\pm 1.54 \mathrm{~min}$, and the $P$-values for linear and quadratic effects were $<0.01$ and $<0.01$, respectively. Color version available online.

and $\mathrm{CR}$ had greater BCS and lost less BCS and BW. Rectal temperature measured at the afternoon milking was lower $(P<0.01)$ for cows fed diets containing NDF from $\mathrm{SH}$ and $\mathrm{CR}$.

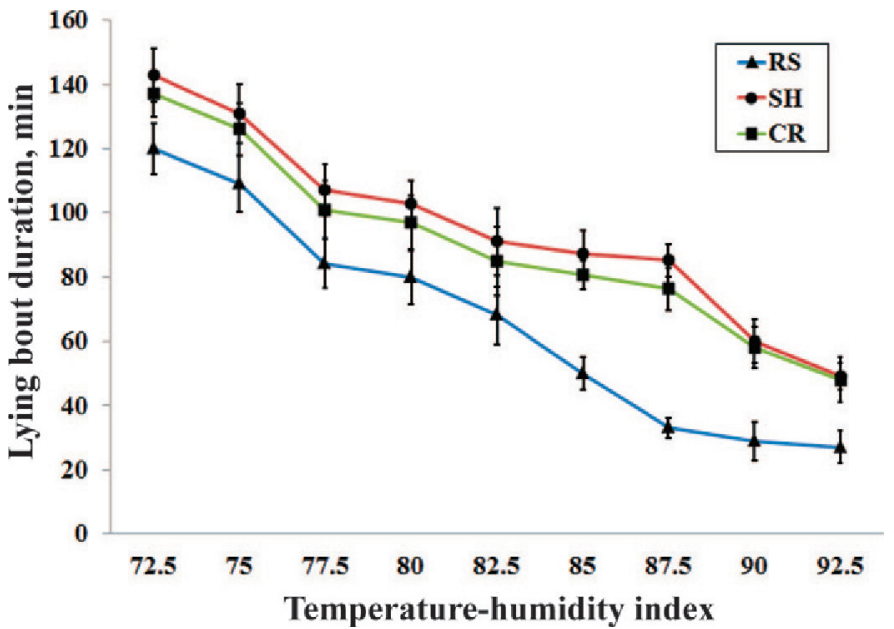

Figure 2. Changes in lying bout duration (min) related to temperature-humidity index (THI) in cows fed diet containing rice straw (RS), soy hulls (SH), or cassava residues (CR). The data for lying bout duration during the night were at and below THI of 82.5 and those during the day were above THI of 82.5. Lying bout duration SEM was $\pm 37.9 \mathrm{~min}$, and the $P$-values for linear and quadratic effects were $<0.01$ and 0.15 , respectively. Color version available online.

Production variables, energy balance, and efficiency of milk production are shown in Table 4. Milk yield and $4 \%$ FCM yield were greater $(P<0.01)$ in cows fed diets containing NDF from SH and CR. Milk fat $(P=0.02)$

Table 2. Feeding and lying behavior for cows fed the experimental diets

\begin{tabular}{|c|c|c|c|c|c|}
\hline \multirow[b]{2}{*}{ Variable } & \multicolumn{3}{|c|}{ Treatment $^{1}$} & \multirow[b]{2}{*}{ SEM } & \multirow[b]{2}{*}{$P$-value } \\
\hline & $\mathrm{RS}$ & $\mathrm{SH}$ & $\mathrm{CR}$ & & \\
\hline \multicolumn{6}{|c|}{ Meal, frequency/d } \\
\hline Day & $8.8^{\mathrm{a}}$ & $7.7^{\mathrm{b}}$ & $7.5^{\mathrm{b}}$ & 0.25 & 0.03 \\
\hline Night & $10.5^{\mathrm{a}}$ & $8.0^{\mathrm{b}}$ & $7.9^{\mathrm{b}}$ & 0.55 & 0.02 \\
\hline Total & $19.3^{\mathrm{a}}$ & $15.7^{\mathrm{b}}$ & $15.4^{\mathrm{b}}$ & 0.67 & 0.02 \\
\hline \multicolumn{6}{|c|}{ Meal length, min/meal } \\
\hline Day & $9.0^{\mathrm{b}}$ & $11.2^{\mathrm{a}}$ & $11.1^{\mathrm{a}}$ & 0.21 & $<0.01$ \\
\hline Night & $10.4^{\mathrm{b}}$ & $15.1^{\mathrm{a}}$ & $15.0^{\mathrm{a}}$ & 0.33 & $<0.01$ \\
\hline Total & $9.7^{\mathrm{b}}$ & $13.2^{\mathrm{a}}$ & $13.1^{\mathrm{a}}$ & 0.29 & $<0.01$ \\
\hline \multicolumn{6}{|c|}{ Meal time, $\min / \mathrm{d}$} \\
\hline Day & 79.2 & 86.2 & 83.3 & 3.63 & 0.44 \\
\hline Night & 109.2 & 120.8 & 118.5 & 7.19 & 0.65 \\
\hline Total & 188.4 & 207.0 & 201.8 & 9.99 & 0.80 \\
\hline \multicolumn{6}{|c|}{ Meal size. ${ }^{2} \mathrm{~kg}$ of $\mathrm{DM} /$ meal } \\
\hline Day & $0.70^{\mathrm{b}}$ & $1.03^{\mathrm{a}}$ & $1.04^{\mathrm{a}}$ & 0.04 & $<0.01$ \\
\hline Night & $0.91^{\mathrm{b}}$ & $1.21^{\mathrm{a}}$ & $1.22^{\mathrm{a}}$ & 0.03 & $<0.01$ \\
\hline Total & $0.81^{b}$ & $1.12^{\mathrm{a}}$ & $1.13^{\mathrm{a}}$ & 0.03 & $<0.01$ \\
\hline \multicolumn{6}{|c|}{ Lving, frequency/d } \\
\hline Day & $6.1^{\mathrm{a}}$ & $4.3^{\mathrm{b}}$ & $4.5^{\mathrm{b}}$ & 0.05 & $<0.01$ \\
\hline Night & 4.5 & 3.9 & 4.0 & 0.10 & 0.29 \\
\hline Total & $10.6^{\mathrm{a}}$ & $8.2^{\mathrm{b}}$ & $8.5^{\mathrm{b}}$ & 0.14 & $<0.01$ \\
\hline \multicolumn{6}{|c|}{ Lying duration. $\mathrm{h} / \mathrm{d}$} \\
\hline Day & $3.4^{\mathrm{b}}$ & $6.1^{\mathrm{a}}$ & $5.7^{\mathrm{a}}$ & 0.06 & $<0.01$ \\
\hline Night & 6.3 & 7.0 & 6.7 & 0.13 & 0.40 \\
\hline Total & $9.7^{\mathrm{b}}$ & $13.1^{\mathrm{a}}$ & $12.4^{\mathrm{a}}$ & 0.22 & $<0.01$ \\
\hline
\end{tabular}

${ }^{\mathrm{a}, \mathrm{b}}$ Within a row, means without a common superscript differ $(P<0.05$ or $P<0.01)$.

${ }^{1} \mathrm{RS}=$ rice straw, $\mathrm{SH}=$ soy hulls; $\mathrm{CR}=$ cassava residues.

${ }^{2}$ Meal size $=\mathrm{DMI} /$ number of meals. 
Table 3. Dry matter and nutrient intakes, changes in BCS and BW, and rectal temperature of cows fed the experimental diets

\begin{tabular}{|c|c|c|c|c|c|c|c|}
\hline \multirow[b]{2}{*}{ Variable } & \multicolumn{3}{|c|}{ Treatment $^{1}$} & \multirow[b]{2}{*}{ SEM } & \multicolumn{3}{|c|}{$P$-value ${ }^{2}$} \\
\hline & $\mathrm{RS}$ & $\mathrm{SH}$ & $\mathrm{CR}$ & & $\mathrm{D}$ & $\mathrm{T}$ & $\mathrm{D} \times \mathrm{T}$ \\
\hline \multicolumn{8}{|l|}{ DMI, $\mathrm{kg} / \mathrm{d}$} \\
\hline Day & $6.2^{\mathrm{b}}$ & $7.9^{\mathrm{a}}$ & $7.8^{\mathrm{a}}$ & 0.13 & $<0.01$ & $<0.01$ & $<0.01$ \\
\hline Night & 9.6 & 9.7 & 9.6 & 0.37 & 0.27 & $<0.01$ & 0.29 \\
\hline Total & $15.8^{\mathrm{b}}$ & $17.6^{\mathrm{a}}$ & $17.4^{\mathrm{a}}$ & 0.27 & $<0.01$ & $<0.01$ & $<0.01$ \\
\hline DMI, $\%$ of BW & $3.2^{\mathrm{b}}$ & $3.6^{\mathrm{a}}$ & $3.5^{\mathrm{a}}$ & 0.03 & $<0.01$ & $<0.01$ & $<0.01$ \\
\hline $\mathrm{CP}$ intake, $\mathrm{kg} / \mathrm{d}$ & $2.67^{\mathrm{b}}$ & $2.96^{\mathrm{a}}$ & $2.96^{\mathrm{a}}$ & 0.02 & $<0.01$ & $<0.01$ & $<0.01$ \\
\hline Total NDF intake, $\mathrm{kg} / \mathrm{d}$ & $3.97^{\mathrm{b}}$ & $4.40^{\mathrm{a}}$ & $4.38^{\mathrm{a}}$ & 0.08 & $<0.01$ & $<0.01$ & $<0.01$ \\
\hline Roughage NDF intake, $\mathrm{kg} / \mathrm{d}$ & $2.20^{\mathrm{a}}$ & $1.76^{\mathrm{b}}$ & $1.74^{\mathrm{b}}$ & 0.07 & $<0.01$ & $<0.01$ & $<0.01$ \\
\hline $\mathrm{NE}_{\mathrm{L}}$ intake, Mcal/d & $25.9^{\mathrm{b}}$ & $29.04^{\mathrm{a}}$ & $28.54^{\mathrm{a}}$ & 0.53 & $<0.01$ & $<0.01$ & $<0.01$ \\
\hline BCS ${ }^{3}$ units & $2.13^{\mathrm{b}}$ & $2.45^{\mathrm{a}}$ & $2.44^{\mathrm{a}}$ & 0.05 & 0.03 & $<0.01$ & 0.21 \\
\hline BCS, change & $-0.39^{\mathrm{b}}$ & $-0.23^{\mathrm{a}}$ & $-0.24^{\mathrm{a}}$ & 0.02 & 0.04 & & \\
\hline $\mathrm{BW}, \mathrm{kg}$ & 490 & 489 & 492 & 11.42 & 0.15 & $<0.01$ & 0.68 \\
\hline BW change, $\mathrm{kg} / \mathrm{d}$ & $-0.508^{b}$ & $-0.333^{\mathrm{a}}$ & $-0.349^{\mathrm{a}}$ & 0.03 & 0.02 & & \\
\hline \multicolumn{8}{|l|}{ Rectal temperature, ${ }^{\circ} \mathrm{C}$} \\
\hline $0430 \mathrm{~h}$ milking & 39.08 & 39.09 & 39.09 & 1.77 & 0.80 & 0.88 & 0.91 \\
\hline $1530 \mathrm{~h}$ milking & $39.74^{\mathrm{a}}$ & $39.26^{\mathrm{b}}$ & $39.27^{\mathrm{b}}$ & 0.29 & $<0.01$ & 0.55 & 0.59 \\
\hline
\end{tabular}

${ }^{\mathrm{a}, \mathrm{b}}$ Within a row means without a common superscript differ $(P<0.05$ or $P<0.01)$.

${ }^{1} \mathrm{RS}=$ rice straw, $\mathrm{SH}=$ soy hulls; $\mathrm{CR}=$ cassava residues.

${ }^{2} \mathrm{D}=$ dietary treatment; $\mathrm{T}=$ week after calving

${ }^{3} \mathrm{BCS}$ on $1=$ thin to $5=$ obese scale with quarter-point increments.

was affected by dietary treatment. Milk fat was lower in cows fed the diets containing NDF from SH and CR. Energy balance was greater $(P<0.01)$ in cows fed diets containing NDF from SH and CR. Dietary treatment had no effect on other milk components or efficiency of milk production (FCM/DMI).

\section{DISCUSSION}

Temperature-humidity index is a good predictor for heat stress in dairy cows (Dikmen and Hansen, 2009). Although crossbred Holstein cows in this study were expected to be heat tolerant to some extent, Chaiyabutr et al. (2008), using cows of a similar breed type, stage of lactation, and housed under similar environmental conditions to those of the current study, reported that noncooled cows fed a diet containing 25\% roughage NDF ate $20 \%$ less feed and produced 30\% less milk compared with cooled cows. In this study, cows were under severe (THI 86.4 to 91.5, daytime) and moderate (THI 74.2 to 81.0 , nighttime) heat stress.

The initial response to heat stress in lactating cows is to reduce feed intake (Collier et al., 1982). In this study, duration of feeding and lying bouts decreased with increasing THI. The shorter duration of feeding bouts was translated into greater feeding frequency and shorter meal length and therefore lower rate of intake. The greater frequency of standing meant that these

Table 4. Production variables and energy balance for cows fed the experimental diets

\begin{tabular}{|c|c|c|c|c|c|c|c|}
\hline \multirow[b]{2}{*}{ Variable } & \multicolumn{3}{|c|}{ Treatment $^{1}$} & \multirow[b]{2}{*}{ SEM } & \multicolumn{3}{|c|}{$P$-value ${ }^{2}$} \\
\hline & $\mathrm{RS}$ & $\mathrm{SH}$ & $\mathrm{CR}$ & & $\mathrm{D}$ & $\mathrm{T}$ & $\mathrm{D} \times \mathrm{T}$ \\
\hline Milk, kg/d & $24.4^{\mathrm{b}}$ & $27.3^{\mathrm{a}}$ & $26.5^{\mathrm{a}}$ & 0.60 & $<0.01$ & $<0.01$ & 0.70 \\
\hline Milk fat, $\%$ & $3.90^{\mathrm{a}}$ & $3.74^{\mathrm{b}}$ & $3.72^{\mathrm{b}}$ & 0.11 & 0.02 & $<0.01$ & 0.92 \\
\hline Milk fat, $\mathrm{kg} / \mathrm{d}$ & 0.95 & 1.02 & 0.99 & 0.10 & 0.60 & $<0.01$ & 0.53 \\
\hline Milk protein, $\%$ & 2.76 & 2.87 & 2.86 & 0.08 & 0.72 & $<0.01$ & 0.69 \\
\hline Milk protein, $\mathrm{kg} / \mathrm{d}$ & 0.67 & 0.78 & 0.76 & 0.05 & 0.08 & $<0.01$ & 0.88 \\
\hline Milk lactose, $\%$ & 4.90 & 4.91 & 4.96 & 0.09 & 0.45 & 0.51 & 0.40 \\
\hline Milk lactose, $\mathrm{kg}$ & 1.20 & 1.34 & 1.31 & 0.08 & 0.33 & $<0.01$ & 0.39 \\
\hline FCM, $4 \%, \mathrm{~kg} / \mathrm{d}$ & $24.0^{\mathrm{b}}$ & $26.2^{\mathrm{a}}$ & $25.4^{\mathrm{a}}$ & 0.52 & $<0.01$ & $<0.01$ & 0.70 \\
\hline FCM/DMI & 1.52 & 1.49 & 1.46 & 0.09 & 0.48 & 0.36 & 0.41 \\
\hline Energy balance, Mcal/d & $-1.78^{\mathrm{b}}$ & $-0.46^{\mathrm{a}}$ & $-0.43^{\mathrm{a}}$ & 0.07 & $<0.01$ & $<0.01$ & 0.39 \\
\hline
\end{tabular}


cows had longer standing bouts throughout the day. A lower rate of intake and shorter duration of meals are key factors in determining the energy cost of eating (Adam et al., 1984). Cows spend more time standing without feeding and less time lying as heat load increased (Legrand et al., 2011). Given that the shorter durations of feeding and lying bouts observed in these cows were associated with lower DMI and milk yield, it could be hypothesized that, in addition to reduced DMI, heat load induced by the behavioral patterns may directly affect milk yield. In addition, the effect was more pronounced when early lactation cows were fed the higher roughage diet compared with NFFS diets. These changes in behavioral patterns were accompanied by an increase in the $1530 \mathrm{~h}$ rectal temperatures of cows fed the higher roughage NDF diet, which could be reflected in a higher heat load (Legrand et al., 2011).

Several changes occur in feeding behavior of dairy cows from early to peak lactation. Dairy cows show a proportional increase in the number of meals, meal length, and daily meal time from early to peak lactation (DeVries et al., 2003). In the current study, cows fed diets containing NDF from SH and CR had fewer meals, whereas meal length and meal size were greater. These changes in feeding behavior were accompanied by an increase in DMI. These results suggested that, under heat stress conditions, early lactation cows fed diets containing NFFS increased DMI by increasing meal length and meal size rather than by increasing meal frequency.

Roughage NDF limits intake by early lactating cows (Randby et al., 2012). Cows fed a high roughage diet spend more time eating and ruminating (Nielsen et al., 2000). Although cows consuming the 3 dietary treatments in the current study spent similar amounts of time per day eating (188 to $207 \mathrm{~min}$ ), cows fed diets containing roughage NDF consumed smaller meals and consumed meals more frequently. These changes in feeding behavior were accompanied by a reduction in DMI, particularly during the day. These findings are supported by the $1530 \mathrm{~h}$ rectal temperature, which was higher in the diets containing NDF from RS. Tropical roughage containing less easily digested NDF (Wilson et al., 1989) was more filling over time and it led to less capacity in the reticulo-rumen, leading to smaller meal size and meal length in the current study. Because the meal size was smaller, hunger presumably occurs sooner, resulting in a shorter interval between meals and therefore a greater frequency of meals. For cows fed more hydrolyzed NDF from SH (Ipharraguerre and Clark, 2003) and CR (Kanjanapruthipong and Buatong, 2004), the opposite would be expected. In addition, higher roughage diets have a higher heat increment (McDowell et al., 1976). Therefore, minimiz- ing the filling effect of feed becomes more important for heat-stressed early lactation cows, as its effect may minimize the heat produced associated with the changes in feeding behavior and heat increment.

The negative effects of short periods (even only for 2 h) of lying deprivation, if repeated, may impair animal well-being in the long term, because lying-deprived cows exhibit physical discomfort (Cooper et al., 2007). As THI increases, the duration of lying during the day significantly decreases (Zähner et al., 2004) and lying time decreases from $10.9 \pm 0.48$ to $7.9 \pm 0.48 \mathrm{~h} / \mathrm{d}$ from the coolest to the hottest period during the day (Cook et al., 2007). In the current study, cows fed the diet containing NDF from RS spent less time lying down $(9.7 \pm 0.18 \mathrm{~h} / \mathrm{d})$ than those fed diets containing SH and CR $(13.1 \pm 0.24$ and $12.4 \pm 0.25 \mathrm{~h} / \mathrm{d}$, respectively). In addition, cows fed the diet containing NDF from RS lay down more frequently and spent less time lying during the day, possibly to increase heat dissipation. These changes in lying behavior were accompanied by an increase in the $1530 \mathrm{~h}$ rectal temperatures of $0.47^{\circ} \mathrm{C}$, which could reflect the higher heat load (Legrand et al., 2011). The amount of energy cows expended from the 2.7 to $3.4 \mathrm{~h} / \mathrm{d}$ extra standing time during the day is not known. The restlessness from $\sim 3 \mathrm{~h}$ of extra standing time must be considered as a factor that impairs animal well-being (Metz, 1985). During the period of standing, leg stomping, repositioning, butting, and weight shifting (displacing weight from one side of the body to the other) may serve to reduce physical discomfort by alleviating strain in the cow's legs and hooves (Cooper et al., 2007).

Body temperature rises when heat load exceeds heat dissipation, and increased heat load is associated with increasing THI (Zähner et al., 2004), milk production (Purwanto et al., 1990), and fiber contents in diets (Stott and Moody, 1960). Under heat stress conditions, rectal temperature increases were greatest for early lactation cows at higher production compared with lower-yielding mid- and late-lactation cows (Johnson et al., 1988). In the current study, cows fed the diet containing NDF from RS ate more frequently, consumed smaller meals, and spent less time lying down. Cows consuming less feed and producing less milk would be expected to produce less body heat and thus less heat to be dissipated, which is reflected in the lower rectal temperature. Surprisingly, replacing NDF from SH and CR with NDF from RS in this study resulted in lower DMI and FCM and greater rectal temperatures. These feeding and lying activities may contribute to the greater heat load in the severely heat-stressed early lactation cows fed a higher roughage NDF diet.

Decreased DMI accounts for only approximately $50 \%$ of the heat stress-induced decrease in milk produc- 
tion, and changes in postabsorptive metabolism may account for a large portion of the remainder of milk loss (Baumgard et al., 2011). In this study, early lactation cows fed the diet containing NDF from RS showed decreased DMI and FCM and lost body condition and BW, despite the lack of difference in calculated FCM/ DMI. The average 63-d postpartum EB in this study was $-1.78,-0.46$, and $-0.43 \mathrm{Mcal} / \mathrm{d}$ for cows fed diets containing $\mathrm{RS}, \mathrm{SH}$, and $\mathrm{CR}$, respectively. The cows fed the diet containing NDF from RS may have mobilized a greater amount of their body tissue to support milk synthesis. These results suggest that the higher maintenance cost derived from the filling effect-induced change in feeding and lying behavior may impair productivity of severely heat-stressed early lactation cows fed a higher roughage diet compared with NFFS diets.

\section{CONCLUSIONS}

As THI was increased, the duration of feeding and lying bouts was decreased. Heat-stressed early lactating cows fed diets containing $\mathrm{NDF}$ from $\mathrm{SH}$ and $\mathrm{CR}$ increased DMI, particularly during the day, by increasing meal length and meal size rather than by increasing meal frequency. Although DMI during the night was not different, the cows fed the diet containing NDF from NFFS ate less frequently and had greater meal length and meal size. They spent more time lying and lay down less often. They also produced greater FCM, lost less body condition and BW, and had lower rectal temperatures. Therefore, reducing the filling effect may contribute to reducing heat load derived from these physical activities. This should be considered as a factor impairing productivity of heat-stressed early lactation cows.

\section{ACKNOWLEDGMENTS}

This research was funded by the Kasetsart University Research and Development Institute (Kasetsart University, Thailand). The authors gratefully acknowledge the assistance of staff at the WataKan dairy farm at Kampaengsaen (Nakornpathom Province, Thailand) in conducting this experiment.

\section{REFERENCES}

Adam, I., B. A. Young, A. M. Nicol, and A. A. Regen. 1984. Energy cost of eating in cattle given diets different forms. Anim. Prod. 38:53-56.

AOAC. 1980. Official Methods of Analysis. 13th ed. Association of Official Analytical Chemists, Washington, DC.

Baumgard, L. H., J. B. Wheelock, S. R. Sanders, C. E. Moore, H. B. Green, M. R. Waldron, and R. P. Rhoads. 2011. Postabsorptive carbohydrate adaptations to heat stress and monensin supplementation in lactating Holstein cows. J. Dairy Sci. 94:5620-5633.
Chaiyabutr, N., S. Chanpongsang, and S. Suadsong. 2008. Effects of evaporative cooling on the regulation of body water and milk production in crossbred Holstein cattle in a tropical environment. Int. J. Biometeorol. 52:575-585.

Chapinal, N., A. M. de Passille, and J. Rushen. 2009. Weight distribution and gait in dairy cattle are affected by milking and late pregnancy. J. Dairy Sci. 92:581-588.

Collier, R. J., D. K. Beede, W. W. Thatcher, L. A. Israel, and C. J. Wilcox. 1982. Influences of environment and its modification on dairy animal health and production. J. Dairy Sci. 65:2213-2227.

Cook, N. B., R. L. Mentink, T. B. Bennett, and K. Burgi. 2007. The effect of heat stress and lameness on time budgets of lactating dairy cows. J. Dairy Sci. 90:1674-1682.

Cooper, M. D., D. R. Arney, and C. J. C. Phillips. 2007. Two- or fourhour lying deprivation on the behavior of lactating dairy cows. J. Dairy Sci. 90:1149-1158.

DeVries, T. J., M. A. G. von Keyserlingk, D. M. Weary, and K. A. Beauchemin. 2003. Measuring the feeding behavior of lactating dairy cows in early to peak lactation. J. Dairy Sci. 86:3354-3361.

Dikmen, S., and P. J. Hansen. 2009. Is the temperature-humidity index the best indicator of heat stress in lactating dairy cows in a subtropical environment? J. Dairy Sci. 92:109-116.

Halachmi, I., E. Maltz, N. Livshin, A. Antler, D. Ben-Ghedalia, and J. Miron. 2004. Effects of replacing roughage with soy hulls on feeding behavior and milk production of dairy cows under hot weather conditions. J. Dairy Sci. 87:2230-2238.

Ipharraguerre, I. R., and J. H. Clark. 2003. Soyhulls as an alternative feed for lactating dairy cows: a review. J. Dairy Sci. 86:1052-1073.

Johnson, H. D., M. Shanklin, and L. Hahn. 1988. Productive adaptability of Holstein cows to environmental heat. Res. Bull. No. 1060. Univ. Missouri Agric. Exp. Stn., Columbia.

Kanjanapruthipong, J., and N. Buatong. 2004. Effects of replacing nonfiber carbohydrates with nonforage detergent fiber from cassava residues on performance of dairy cows in the tropics. Asianaustralas. J. Anim. Sci. 17:967-972.

Kanjanapruthipong, J., N. Homwong, and N. Buatong. 2010. Effects of prepartum roughage neutral detergent fiber levels on periparturient dry matter intake, metabolism, and lactation in heat-stressed dairy cows. J. Dairy Sci. 93:2589-2597.

Legrand, A., K. E. Schütz, and C. B. Tucker. 2011. Using water to cool cattle: Behavioral and physiological change associated with voluntary use of cow showers. J. Dairy Sci. 94:3376-3386.

McDowell, R. E., N. W. Hooven, and J. K. Camoens. 1976. Effect of climate on performance of Holsteins in first lactation. J. Dairy Sci. 59:965-973.

Metz, J. H. M. 1985. The reaction of cows to short-term deprivation of lying. Appl. Anim. Behav. Sci. 13:301-307.

Morita, S., S. Devir, C. C. K. Lauwere, A. C. Smiths, H. Hogeveen, and J. H. M. Metz. 1996. Effects of concentrate intake on subsequent roughage intake and eating behavior of cows in an automatic milking system. J. Dairy Sci. 79:1572-1580.

Munksgaard, L., M. B. Jensen, L. J. Pedersen, S. W. Hansen, and L. Matthews. 2005. Quantifying behavioural priorities-Effects of time constrain on behavior of dairy cows, Bos taurus. Appl. Anim. Behav. Sci. 92:3-14.

Nielsen, B. L., R. F. Veerkamp, and A. B. Lawrence. 2000. Effects of genotype, feed type and lactational stage on the time budget of dairy cow. Acta Agric. Scand. Anim. Sci. 50:272-278.

Nishida, T., K. Hosoda, H. Matsuyama, and M. Ishida. 2004. Effect of lying behavior on uterine blood flow in cows during the third trimester of gestation. J. Dairy Sci. 87:2388-2392.

NOAA (National Oceanic and Atmospheric Administration). 1976. Livestock hot weather stress. US Dept. Commerce Natl. Weather Serv. Central Reg., Reg. Operations Man. Lett. C-31-36. NOAA, Washington, DC.

NRC. 2001. Nutrient Requirements of Dairy Cattle. 7th rev. ed. Natl. Acad. Sci., Washington. DC.

Purwanto, B. P., Y. Abo, R. Sakamoto, F. Furumato, and S. Yamamoto. 1990. Diurnal patterns of heat production and heart rate under thermonutral conditions in Holstein Frisian cows differing milk production. J. Agric. Sci. (Camb.) 114:139-142. 
R Foundation. 2009. Version R-2.9.0 ed. R Foundation for Statistical Computing, Vienna, Austria. http://www.r-project.org/.

Randby, A. T., M. R. Weisbjerg, P. N. Ørgaard, and B. Heringstad. 2012. Early lactation feed intake and milk yield responses of dairy cows offered grass silage harvested at early maturity stages. J. Dairy Sci. 95:304-317.

Rhoads, M. L., R. P. Rhoads, M. J. VanBaale, R. J. Collier, and S. R. Sanders. W. J. Weber, B. A. Crooker, and L. H. Baumgard. 2009. Effects of heat stress and plane of nutrition on lactating Holstein cows: I. Production, metabolism, and aspects of circulating somatotropin. J. Dairy Sci. 92:1986-1997.

Rulquin, H., and J. P. Caudal. 1992. Effects of lying or standing on mammary blood flow and heart rate of dairy cows. Ann. Zootech (Paris) 41:41-48.

Shiao, T. F., J. C. Chen, D. W. Yang, S. N. Lee, C. F. Lee, and W. T. K. Cheng. 2011. Feasibility assessment of a tunnel-ventilated, water-padded barn on alleviation of heat stress for lactating Holstein cows in humid area. J. Dairy Sci. 94:5393-5404.
Stott, G. H., and E. G. Moody. 1960. Tolerance of dairy cows to high climatic temperatures on low roughage ration. J. Dairy Sci. 43:871. (Abstr.)

Van Soest, P. J., J. B. Robertson, and B. A. Lewis. 1991. Methods for dietary fiber, neutral detergent fiber, and nonstarch polysaccharides in relation to animal nutrition. J. Dairy Sci. 74:3583-3597.

Wildman, E. E., G. M. Jones, P. E. Wagner, R. L. Boman, H. F. Troutt, and T. N. Lesch. 1982. A dairy cow body condition scoring system and its relationship to selected production characteristics. J. Dairy Sci. 65:495-501.

Wilson, J. R., M. N. McLeod, and D. J. Minson. 1989. Particle size reduction of the leaves of a tropical and a temperate grass by cattle. I. Effect of chewing during eating and varying times of digestion. Grass Forage Sci. 44:45-63.

Zähner, M., L. Schrader, R. Hauser, M. Keck, W. Langhans, and B. Wechsier. 2004. The influence of climatic conditions on physiological and behavioural parameters in dairy cows kept in open stables. Anim. Sci. 78:139-147. 